migrated along the fault plane over a minimum distance of $800 \mathrm{~m}$ which is the estimated depth to the bottom of the basalts. Because of the biodegradation there is no indication of the nature of the source of the material. However, both the Upper Permian Posidonia Shale and Upper Jurassic Hareelv Formation are known to have source rock potential in the Jameson Land basin, and a southwards extension of these could well have produced these hydrocarbons (Surlyk et al., 1984). The existence of other source rocks beneath the basalts cannot be excluded.

\title{
References
}

Birkelund, T. \& Perch-Nielsen, K. 1976: Late Palaeozoic - Mesozoic evolution of central East Greenland. In Escher. A. \& Watt, W. S. (edit.) Geology of Greenland, 304-339. Copenhagen: Geol. Surv. Greenland.

Halliday, G., Kliim-Nielsen, L. \& Smart, I. H. M. 1974: Studies on the flora of the northern Blosseville Kyst and on the hot springs of Greenland. Meddr Grønland 199 (2), 49 pp.

Surlyk, F., Hurst, J. M., Marcussen, C., Piasecki, S., Rolle, F., Scholle, P. A., Stemmerik, L. \& Thomsen, E. 1984: Oil geological studies in the Jameson Land basin, East Greenland. Rapp. Grønlands geol. Unders. 120, this report.

Watt, M. 1975: Photo-reconnaissance of the Blosseville Kyst between Steward Ø and Søkongens Bugt, central East Greenland. Rapp. Grønlands geol. Unders. 75, 91-95.

Watt, W. S. \& Watt, M. 1983: Stratigraphy of the basalts of Savoia Halvø, central East Greenland. Rapp. Grønlands geol. Unders. 115, 83-88.

\section{Oil geological studies in the Jameson Land basin, East Greenland}

\author{
F. Surlyk, J. M. Hurst, C. Marcussen, S. Piasecki, F. Rolle, P. A. Scholle, \\ L. Stemmerik and E. Thomsen
}

An oil geological project was started in Jameson Land in 1982 (Surlyk, 1983; Surlyk et al., in press). The field work part of the project was completed in 1983. A major source rock programme, focusing on the evaluation of potential onshore and offshore source rocks, is central to the project.

The technical personnel J. Boserup, A. Clausen and K. Villadsen worked on the shallow core drilling crew, whilst E. Thomsen, S. Piasecki, C. Marcussen, F. Rolle and F. Surlyk alternated as well-site geologists. In 1983 a total of nine holes were drilled mainly to depths of about $30 \mathrm{~m}$ (fig. 36). One hole was drilled in Upper Permian bioturbated siltstone at Domkirken south of Mestersvig (1, fig. 36); one in Upper Permian carbonate and black shale at Rødstaken, eastern side of Schuchert Dal (2, fig. 36); one in Upper Permian carbonate at Revdal (3, fig. 36), and one in Upper Permian limestone and black shale in the southern part of Karstryggen, western side of Schuchert Dal (9, fig. 36); two in Devondal, 


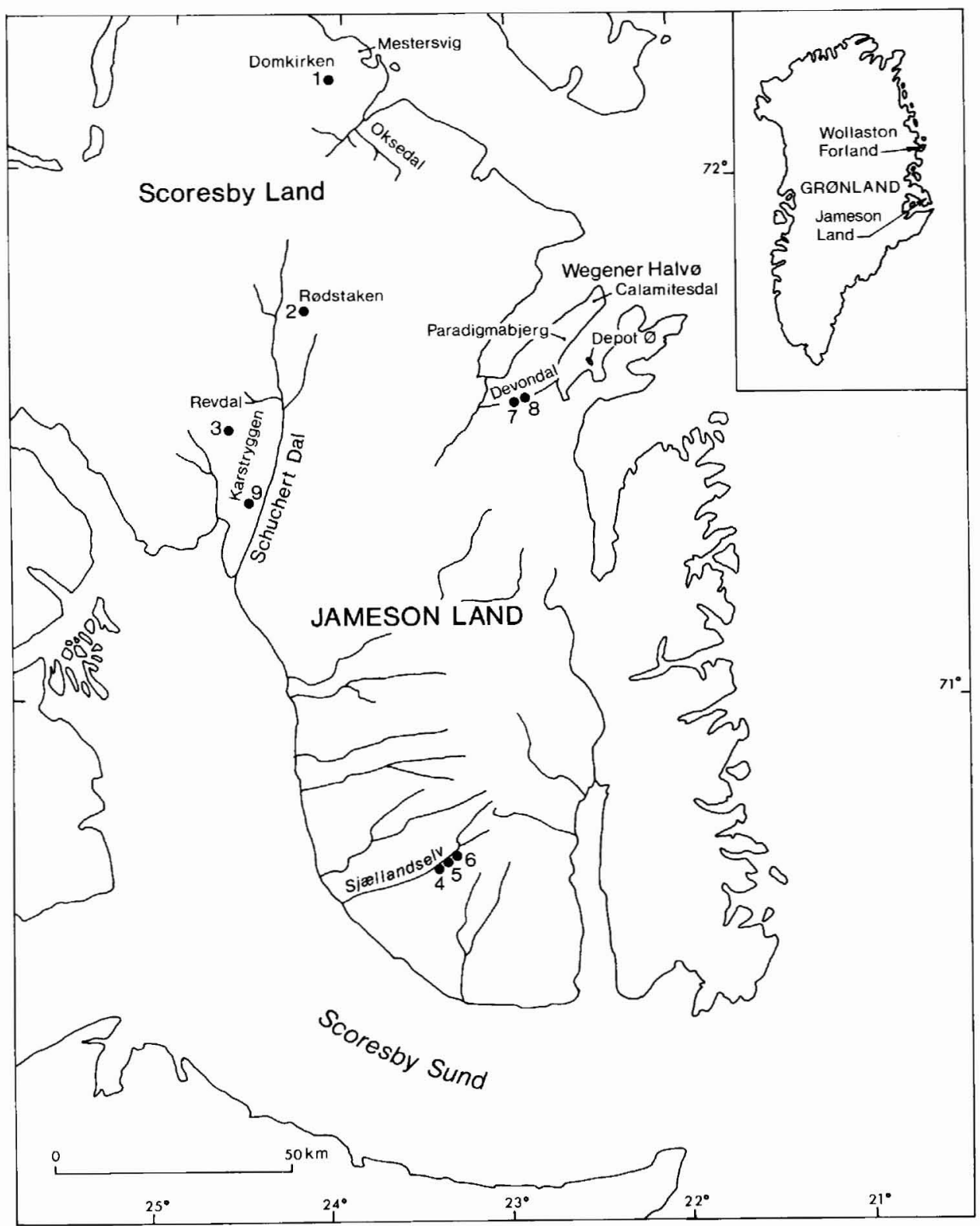

Fig. 36. Geographical localities mentioned in the text and 1983 core hole drill sites in Jameson Land and Scoresby Land. 
the first in Upper Permian reef carbonate (7, fig. 36) and the second in Upper Permian black shale and Lower Triassic shale (8, fig. 36); three in the Upper Jurassic Hareelv Formation at Sjællandselv $(4,5,6$, fig. 36). The core recovery was approximately 95 per cent and a total of 317 cumulative metres were drilled. The main objective of drilling both in 1982 and 1983 was the Upper Permian black shale, which is considered to be promising as a possible source rock in Jameson Land.

In addition to the drilling programme detailed stratigraphic and sedimentological studies were undertaken in the Lower Permian, Upper Permian and lowermost Triassic sequences.

\section{Lower Permian}

Early Permian deposition took place in a system of alluvial fans formed along the main western border fault. Fan sediments are mainly coarse-grained red beds. Some distance from the fault in the Schuchert Dal area the fan facies gradually gives way to thick grey cyclical sandstone-mudstone sequences deposited in a major northward draining floodplain which was located in the central part of the basin.

The resulting thick continental sequence has previously been attributed a general Late Carboniferous - Early Permian age. In 1982 and 1983 intensive palynological sampling has been undertaken by S. Piasecki and more than 400 samples from the Permian - Lower Triassic sequence have been processed. The palynological analyses have shown that the age of the alleged Upper Carboniferous - Upper Permian sediments is Early Permian (Autunian) throughout. There is only a small possibility that the lowest part of the sequence extends downwards into the uppermost Carboniferous. Thus a Lower Permian Potonieisporites assemblage is recognised in all palynologically productive fine-grained sediments of this unit from the area south of Mestersvig, as well as in the area around Schuchert Dal (Piasecki, in press).

\section{Upper Permian}

After an important mid-Permian tectonic event followed by peneplainization the area was slowly transgressed by the Late Permian sea. Upper Permian deposits are dated by brachiopods, conodonts and the ammonite Cyclolobus kullingi. They contain a Vittatina dominated pollen assemblage in the lower part suggestive of an early Late Permian age, whilst the upper part is characterised by a Protohaploxypinus assemblage of Late Permian (Kazanian-Tatarian) affinities (Piasecki, in press). Several large limestone samples were collected to get a better idea of the content and stratigraphic utility of conodonts. The samples are at present being studied by S. Stouge (University of Copenhagen).

Along the western basin margin an evaporite belt was formed during the early phases of the transgression. The evaporites were studied by L. Stemmerik (University of Copenhagen). Continued transgression eventually led to the development of marine carbonates along the western basin margin and over structural highs, notably Wegener Halvø. The western carbonate belt and in particular the diagenetic aspects of the carbonates were studied by P. A. Scholle (U.S. Geological Survey, Denver, Colorado; now Gulf Oil, Houston). The carbonates on Wegener Halvø were studied by J. M. Hurst with the aim to evaluate the depositional environments and to establish a lithostratigraphy. All carbonate facies were sampled to obtain a thorough understanding of microfacies. The Permian carbonates of 
Wegener Halvø can be sub-divided into two units. A lower unit varying between 40 and 100 $\mathrm{m}$ in thickness consists of well-bedded cryptalgal laminites interbedded with sheet flood conglomerates composed entirely of cryptalgal laminite clasts. Solution breccias commonly occur in isolated pockets in the basal part of the sequence. In one locality in Calamitesdal (fig. 36) calcite replacement of gypsum nodules occurs in association with the solution breccias. At least three distinct subaerial erosion surfaces are present in this lower sequence, but due to their localised nature it is not possible to confidently correlate them between individual sections. Fissures and solution pipes, filled with red silt, are associated with the surfaces. A major undulating subaerial erosion surface with a relief of about $20 \mathrm{~m}$ tops this lower section. This is well displayed at Paradigmabjerg (fig. 36).

The upper limestone unit consists of a complex series of reefs. Preliminary findings indicate a lower reef tract of small stromatolite reefs with a domal diameter of 5-20 m, and a height of 3-5 m. The uppermost reef tract is up to $100 \mathrm{~m}$ thick (e.g. Devondal; fig. 36) and consists of anastomosing reefs. They appear to have a mud core with a diverse fauna and much fibrous calcite cement. They are surrounded by brachiopod shell beds which tail off into thin-bedded calcarenitic turbidites.

The reefs are interbedded with the black shale suggesting that the two units are essentially contemporaneous and that the transgression resulting in the shale also promoted reef development.

A newly discovered locality exposing the lateral carbonate to shale transition in the southern part of Karstryggen (drill site 9, fig. 36) was examined for one day by geologists from ARCO and Nordisk Mineselskab together with J. M. Hurst and F. Surlyk. Later the section was studied in detail by Hurst and Surlyk while a core was drilled through the sequence. To the west an intertidal hypersaline stromatolite dominated platform existed which passed to the east into subtidal carbonates deposited as large stromatolitic domes. The boundaries between facies belts are characteristically developed as 5-10 m high subvertical slopes. The basinal black shale facies overlies the distal subtidal units and can be traced westwards transgressing successively younger carbonate units corresponding to the progressing transgression of the area.

The locality is particularly important as it is the only occurrence of the black shale facies west of Schuchert Dal. Before its discovery (by O. Harpøth, Nordisk Mineselskab) the shales could only be studied in a N-S strike section on the slopes east of Schuchert Dal.

Geochemical and sedimentological data from the new locality will thus be important in evaluating coast to basin trends in this potential source rock facies.

The younger parts of the Permian were studied mainly by F. Rolle. They consist of siliciclastic sediments including shale, sandstone and conglomerate. The organic rich, well laminated black shale facies occurs in most areas where Permian rocks crop out. It varies rather markedly in thickness from $1-60 \mathrm{~m}$, and is overlain by up to $180 \mathrm{~m}$ of bioturbated siltstone, sandstone, coarse arkose, and conglomerate exhibiting an overall upwards coarsening and shallowing sequence.

Of special interest is the find of pyrobitumen impregnated fossils and fissures in the basal part of the Triassic Wordie Creek Formation in Wegener Halvø and Oksedal. This shows that oil has been generated and migrated, most likely from the Upper Permian black shale facies. The higher sandstone units were sampled for porosity and permeability analyses by C. Marcussen.

The existence of a Late Permian intrusive phase was demonstrated by Stemmerik \& 
Sørensen (1980). C. Marcussen collected nine oriented dyke samples for palaeomagnetic measurements and radiometric age dating, and F. Rolle found and sampled a possible pillow-basalt breccia which occurs in the gypsum sequence east of Schuchert Dal. Likewise an igneous plug in Oksedal was sampled for radiometric dating.

\section{Triassic}

The Permo-Triassic boundary was studied at several localities. In the western part of the area there were no visible breaks at the boundary, while evidence of marked erosion is common on Wegener Halvø. J. M. Hurst, F. Rolle, L. Stemmerik and F. Surlyk studied the enigmatic Permo-Triassic boundary sequence at Depot $\emptyset$ (fig. 36) by helicopter reconnaissance. The section starts with 20 to $30 \mathrm{~m}$ of well bedded subtidal carbonate wackestone with siliciclastic mud partings $(1-10 \mathrm{~cm})$. The section is unlike any other part of the Permian carbonate sequence of Jameson Land. The carbonates give way to a thick sequence of bioturbated and fossiliferous pebbly sandstone of uncertain and much debated age (see Säve-Söderbergh, 1936; Maync, 1942; Grasmück \& Trümpy, 1969; Teichert \& Kummel, 1976). The section is topped by four metres of greenish black shale with lowermost Triassic ammonites.

The basal part of the Triassic Wordie Creek Formation contains a pollen assemblage characterised by Taeniaesporites (Piasecki, in press), as well as ammonites diagnostic of several Early Triassic zones (Trümpy, 1969).

No other detailed investigations were undertaken in the Triassic sequence. It should, however, be mentioned that F. Rolle observed an example of intra-Triassic down-to-basin faulting in Devondal (Pingo Dal Formation). The locality was not studied on the ground but it seems to be the first direct observation of Triassic fault tectonics in the Jameson Land basin.

\section{Jurassic}

The Upper Oxfordian - Kimmeridgian Hareelv Formation consists of several hundred metres of black shale with channel sandstone bodies. It is most likely that this formation is the most promising potential source rock in the East Greenland shelf sequence, north of Scoresby Sund.

Three holes were drilled in the formation at Sjællandselv (4, 5, 6, fig. 36) and a number of sandstone samples were collected for porosity-permeability analyses from the overlying Middle Volgian - Valanginian Raukelv Formation.

\section{Other activities}

The Jurassic-Cretaceous boundary beds of Wollaston Forland (fig. 36) were visited for a week by F. Surlyk in connection with studies by Marathon Oil Co. under an early exploration licence.

Acknowledgements. Valuable discussions were held in the field with geologists O. Harpøth (Nordisk Mineselskab), and T. Frazier and C. Goebels (ARCO).

N. Turner and B. Sikker Hansen assisted with the preparation of the manuscript. As in 1982 it is a pleasure to thank I. K. Olsen for his work as a base camp manager. 


\title{
References
}

Grasmück, K. \& Trümpy, R. 1969: Triassic stratigraphy and general geology of the country around Fleming Fjord (East Greenland). Meddr Grønland 168 (2), 5-71.

Maync, W. 1942: Stratigraphie und faziesverhältnisse der Oberpermischen ablagerungen Ostgrönlands. Meddr Grønland 115 (2), 128 pp.

Piasecki, S. in press: Preliminary palyno-stratigraphy of the Permian - Lower Triassic sediments in Jameson Land, East Greenland. Bull. geol. Soc. Denmark 32.

Säve-Söderbergh, G. 1937: On the Palaeozoic stratigraphy of Canning Land, Wegener Peninsula and Depot Island (East Greenland). Meddr Grønland 96 (5), 41 pp.

Stemmerik, L. \& Sørensen, M. 1980: Upper Permian dykes in southern Scoresby Land, East Greenland. Rapp. Grønlands geol. Unders. 100, 108 only.

Surlyk, F. 1983: Source rock sampling, stratigraphical and sedimentological studies in the Upper Palaeozoic of the Jameson Land basin, East Greenland. Rapp. Grønlands geol. Unders. 115, 88-93.

Surlyk, F., Piasecki, S., Rolle, F., Stemmerik, L., Thomsen, E. \& Wrang, P. in press: The Permian basin of East Greenland. In Spencer, A. M. et al. (edit.) Petroleum Geology of the North European Margin. London: Graham \& Trotman.

Teichert, C. \& Kummel, B. 1976: Permian-Triassic boundary in the Kap Stosch area, East Greenland. Meddr Grønland 197(5), 54 pp.

Trümpy, R. 1969: Lower Triassic ammonites from Jameson Land (East Greenland). Meddr Grønland 168(2), 77-121.

L.S.,

Institut for Historisk Geologi

P.A.S.,

og Palceontologi,

Øster Voldgade 10,

DK-1350 Copenhagen $K$.

Gulf Exploration \& Production,

P.O. Box 36506,

Texas 77236 ,

Houston,

U.S.A.

E.T.,

Danmarks Geologiske Undersøgelse,

Thoravej 31,

DK-1350 Copenhagen $K$.

\section{Hydrological modelling in Greenland in connection with hydropower}

\author{
Roger J. Braithwaite
}

There is still interest in the possibility of using runoff for the generation of hydroelectric power in Greenland. However, systematic investigations of the hydrological conditions in the country are relatively recent. For example, the longest runoff series were only started in 1976, while measurements were started even later at potentially attractive sites near to Jakobshavn, Christianshåb, Godthåb, Frederikshåb, and Angmagssalik.

A knowledge of hydrological conditions, especially with respect to annual runoff and its variability, is naturally one of the important components in the planning of hydropower 